\title{
OPEN
}

\section{Publisher Correction: Splice-specific deficiency of the PTSD-associated gene PAC1 leads to a paradoxical age-dependent stress behavior}

\author{
Jakob Biran, Michael Gliksberg, Ido Shirat, Amrutha Swaminathan, Talia Levitas-Djerbi, \\ Lior Appelbaum \& Gil Levkowitz
}

Correction to: Scientific Reports https://doi.org/10.1038/s41598-020-66447-2, published online 12 June 2020

In the original version of this Article, Supplementary Figures 1, 2 and 3 were uploaded as separate supplementary files. Furthermore, the Supplementary Figure Legends for Supplementary Figures 1,2 and 3, as well as a Supplementary Table containing a list of oligonucleotides used for gRNA transcription and RT-PCRs were inadvertently omitted. These errors have been corrected in the Supplementary Information that now accompanies the Article.

\begin{abstract}
(c) (i) Open Access This article is licensed under a Creative Commons Attribution 4.0 International License, which permits use, sharing, adaptation, distribution and reproduction in any medium or format, as long as you give appropriate credit to the original author(s) and the source, provide a link to the Creative Commons license, and indicate if changes were made. The images or other third party material in this article are included in the article's Creative Commons license, unless indicated otherwise in a credit line to the material. If material is not included in the article's Creative Commons license and your intended use is not permitted by statutory regulation or exceeds the permitted use, you will need to obtain permission directly from the copyright holder. To view a copy of this license, visit http://creativecommons.org/licenses/by/4.0/.
\end{abstract}

(C) The Author(s) 2020 